\title{
Efektivitas Modul dengan Model Inkuiri untuk Menumbuhkan Keterampilan Proses Sains Siswa pada Materi Kalor
}

\author{
Eka Puspita Dewi ${ }^{1}$, Agus Suyatna $^{2}$, Abdurrahman $^{2}$, Chandra Ertikanto $^{2}$ \\ ${ }^{1}$ Sekolah Pascasarjana Universitas Lampung; email: ekapuspitadewi35@gmail.com \\ ${ }^{2}$ Pendidikan Fisika Universitas Lampung
}

Diterima: 20 September 2017. Disetujui: 12 November 2017. Dipublikasikan: Desember 2017

\begin{abstract}
The purpose of this study is to findout the effectiveness of module with inquiry model to improve the student's scientific process skill to wards heat material. The research design used was quasi-experimental design in the form of nonequivalent pretest-postest control group design. Based on the results of the effectiveness test, it was known that the value of n-gain experimental class was 0.62. It was greater than the control class with the score was 0.40.Student's scientificprocess skills also increased for each indicator. Based on the research that has been done, it can be concluded that the module by using inquiry modelwasthe effectiveto improve the student's scientific process skills.
\end{abstract}

\begin{abstract}
Abstrak
Tujuan dari penelitian ini adalah untuk mengetahui efektivitas modul untuk menumbuhkan keterampilan proses sains siswa. Desain penelitian yang digunakan adalah quasi experimental design dalam bentuk nonequivalent pretes-postes control group design. Berdasarkan hasil uji efektivitas, maka diketahui bahwa nilai n-gain kelas eksperimen $(0,62)>$ kelas kontrol $(0,40)$. Keterampilan proses sains siswa mengalami peningkatan untuk setiap indikator. Berdasarkan penelitian yang telah dilakukan, dapat disimpulkan bahwa modul dengan model inkuiri telah efektif dalam menumbuhkan keterampilan proses sains siswa.
\end{abstract}

Kata Kunci: Modul, Model Inkuiri, Keterampilan Proses Sains

(C) 2017 URPI, FTK UIN Raden Intan Lampung

\section{PENDAHULUAN}

Pembelajaran fisika dapat menjadi wahana untuk menumbuhkan kemampuan berpikir pada siswa. Untuk mencapai tujuan tersebut diperlukan sumber belajar dan model pembelajaran yang sesuai (Suparwoto, 2007). Selain penggunaan model pembelajaran yang mempengaruhi proses pembelajaran, salah satu keberhasilan dalam pembelajaran sangat bergantung pada penggunaan sumber belajar atau media yang dipakai selama proses pembelajaran (Irwandani \& Rofiah, 2015; Erlinda, 2017; Wijayanti, Maharta, \& Suana, 2017). Salah satu sumber belajar yang tepat dan sesuai untuk belajar secara mandiri adalah modul.

Modul pembelajaran adalah bahan ajar yang disusun secara sistematis dan menarik yang mencakup isi materi, metode dan evaluasi yang dapat digunakan secara mandiri untuk mencapai kompetensi yang diharapkan (Ertikanto, 2017; Nisrokhah, 2016). Dengan ketersediaan modul dapat membantu siswa dalam memperoleh informasi tentang materi pembelajaran (Parmin \& Peniati, 2012). Saat ini modul terbagi dalam dua kategori, yaitu modul yang bersifat cetak dan modul digital (Irwandani, Latifah, Asyhari, Muzannur, \& Widayanti, 2017). Untuk merancang 
materi pembelajaran, terdapat lima kategori kapabilitas yang dapat dipelajari oleh pembelajar, yaitu informasi verbal, keterampilan intelektual, strategi kognitif, sikap, dan keterampilan motorik. Strategi pengorganisasian materi pembelajaran terdiri dari tiga tahapan proses berpikir, yaitu pembentukan konsep, intepretasi konsep, dan aplikasi prinsip. Strategi tersebut memegang peranan sangat penting dalam mendesain pembelajaran inkuiri.

Penelitian sebelumnya yang mengungkapkan penerapan pembelajaran inkuiri ditanggapi positif terhadap pemahaman kemampuan siswa khususnya dalam pembelajaran sains (Dewi, 2016). Pada beberapa penelitian sebelumnya juga menunjukkan bahwa penerapan model inkuiri terbimbing dapat meningkatkan keterampilan proses sains dan hasil belajar siswa (Iswatun, Mosik, \& Subali, 2017) serta membuat aktivitas siswa berkategori baik dalam kelas (Yamin, 2016).

Berdasarkan alasan-alasan yang telah dipaparkan dan melihat keberhasilan penerapan pembelajaran inkuiri sebelumnya, dirasa penting untuk mengetahui efektivitas dari modul yang dirancang berdasarkan model inkuiri untuk menumbuhkan keterampilan proses sains siswa.

\section{METODE PENELITIAN}

Desain penelitian yang digunakan adalah quasi experimental design dalam bentuk nonequivalent pretes-postest group design. Desain ini digunakan untuk melihat perbandingan kemajuan siswa setelah pembelajaran dan sebelum pembelajaran antara kelas eksperimen dan kelas kontrol. Data dalam penelitian diperoleh melalui tes, berupa soal-soal yang ditunjukan kepada siswa. Soal dirancang untuk mengukur keterampilan proses sains siswa.

Analisis data uji efektivitas dilakukan menggunakan analisis statistik terhadap data hasil penelitian dilakukan ujin-gain untuk mengetahui terdapat peningkatan antara pretest dengan postest. Besarnya peningkatan dihitung dengan rumus $N$-Gain ternormalisasi yaitu:

$<g>=\frac{\text { Posttest }- \text { Pretest }}{\text { Skor maksimum }- \text { Pretest }}$

Hasil perhitungan $N$-Gain kemudian diinterpretasikan dengan menggunakan klasifikasi seperti pada Tabel 2 (Meltzer, 2002).

Tabel 2. Klasifikasi N-Gain

\begin{tabular}{ll}
\hline Besarnya g & Interpretasi \\
\hline $\mathrm{g}>0,7$ & Tinggi \\
$0,3<\mathrm{g} \leq 0,7$ & Sedang \\
$\mathrm{g} \leq 0,3$ & Rendah \\
\hline
\end{tabular}

\section{HASIL DAN PEMBAHASAN}

Uji efektivitas modul dilakukan terhadap dua kelas yakni kelas eksperimen dan kelas kontrol. Kelas eksperimen menggunakan modul dengan model inkuiri untuk menumbuhkan keterampilan proses sains (KPS) siswa dalam proses pembelajaran. Sementara itu kelas kontrol adalah kelas yang menggunakan modul yang biasa siswa gunakan oleh siswa dalam pembelajaran. Modul berupa modul pembelajaran yang diperoleh siswa di perpustakaan maupun toko buku.

Uji efektivitas ini dilakukan untuk mengetahui peningkatan nilai pretest dan postest. Selain itu juga untuk mengetahui perbedaan rata-rata nilai pada kelas eksperimen dan kelas kontrol dalam menumbuhkan keterampilan proses sains siswa. Hasil uji efektivitas kelas eksperimen dan kelas kontrol disajikan pada Tabel 3 dan Tabel 4 berikut. 
Tabel 3. Hasil Uji Efektifitas Modul Kelas Eksperimen

\begin{tabular}{|c|c|c|c|c|}
\hline \multirow{4}{*}{ No } & \multirow{4}{*}{ Indikator Keterampilan } & \multicolumn{3}{|c|}{ Kelas Eksperimen } \\
\hline & & \multirow{3}{*}{$\begin{array}{l}\text { Pre- } \\
\text { test }\end{array}$} & \multirow{3}{*}{$\begin{array}{l}\text { Post- } \\
\text { Test }\end{array}$} & \multirow{3}{*}{$\begin{array}{c}\mathrm{N}- \\
\text { Gain } \\
\end{array}$} \\
\hline & & & & \\
\hline & & & & \\
\hline 1 & Memprediksi & 27,6 & 89,2 & 0,84 \\
\hline 2 & Merumuskan Hipotesis & 24.5 & 75,8 & 0,67 \\
\hline 3 & Identifikasi Variabel & 37.6 & 83,0 & 0,73 \\
\hline 4 & Interpretasi Data & 24.7 & 79,4 & 0,72 \\
\hline \multirow[t]{2}{*}{5} & Merumuskan Kesimpulan & 20 & 75 & 0,69 \\
\hline & Total & 36,7 & 76,0 & 0,62 \\
\hline
\end{tabular}

Tabel 4. Hasil Uji Efektifias Modul Kelas Kontrol

\begin{tabular}{llccc}
\hline & & \multicolumn{3}{c}{ Kelas Kontrol } \\
\cline { 3 - 5 } No & \multirow{2}{*}{ Indikator Keterampilan } & & & \\
& & Pre- & Post- & N- \\
& & test & Test & Gain \\
\hline 1 & Memprediksi & 20 & 50.6 & 0,31 \\
2 & Merumuskan Hipotesis & 37.5 & 55 & 0,2 \\
3 & Identifikasi Variabel & 20 & 60 & 0,5 \\
4 & Interpretasi Data & 30 & 60 & 0,42 \\
5 & Merumuskan Kesimpulan & 40 & 55 & 0,25 \\
\hline & Total & 20 & 50 & 0,40 \\
\hline
\end{tabular}

Hasil total uji efektivitas pada kelas eksperimen diperoleh 76,0 untuk postest, dan 36,7 untuk pretest. Sedangkan pada kelas kontrol diperoleh nilai 50,0 untuk postest dan 20 untuk nilai pretest hasil ini menunjukan bahwa nilai postest lebih besar dari nilai pretest. Untuk $N$-Gain kelas eksperimen yaitu 0,62 dengan kategori "sedang". Untuk $\mathrm{N}$-Gain kelas kontrol yaitu 0,40 dengan kategori "sedang". Nilai $N$-Gain kelas eksperimen lebih besar dibandingkan dengan kelas kontrol. Hasil ini menunjukan bahwa modul dengan model inkuiri yang dipakai pada kelas eksperimen lebih efektif dari modul konversional pada kelas kontrol.

Rincian indikator keterampilan proses sains (KPS) pada kelas eksperimen dan kontrol diinterpretasikan pada Gambar 1 berikut.

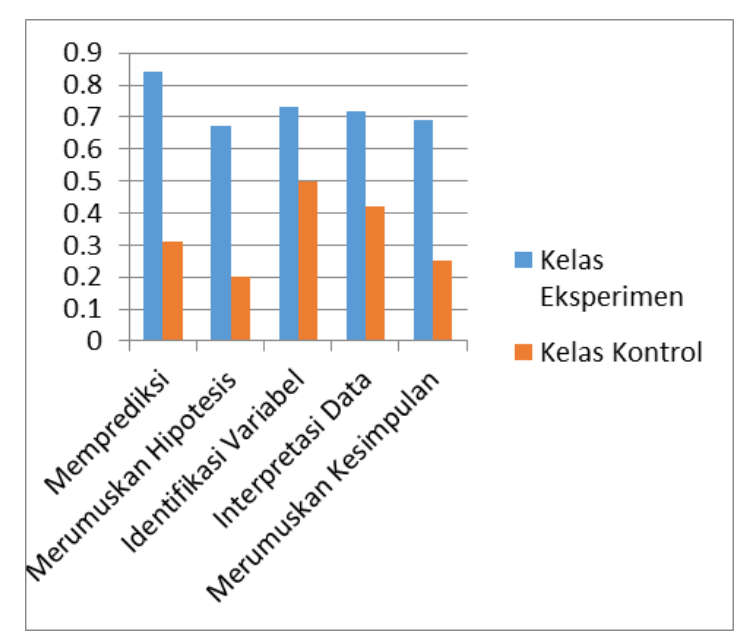

Gambar 1. Grafik Perhitungan Nilai N-Gain Indikator Keterampilan Proses Sains

Gambar 1 menunjukan bahwa $N$ Gain dari indikator keterampilan proses sains yang paling tinggi pada kelas eksperimen adalah memprediksi sedangan pada kelas kontrol indikator yang paling tinggi adalah identifikasi variabel. Hasil perhitungan $\mathrm{N}$-Gain menunjukan bahwa adanya peningkatan keterampilan proses sains siswa dilihat dari nilai pretest dan postest. Pada awalnya keterampilan proses sains siswa berada pada kategori "rendah". Hal ini disebabkan oleh siswa yang masih belum terbiasa untuk memunculkan banyak gagasan untuk berbagai pertanyaan serta belum terbiasa untuk melakukan langkah-langkah secara terperinci.

Setelah menggunakan modul dengan model inkuiri, keterampilan proses sains siswa berada pada kategori "tinggi" .Melalui produk yang telah dikembangkan, siswa diajarkan untuk untuk mencari data melalui kegiatan pemecahan masalah serta melalui langkah-langkah secara terperinci dan sistematis sehingga siswa dapat menjawab berbagai pertanyaan secara bervariasi, sehingga semua indikator keterampilan proses sains yaitu indikator memprediksi, indikator merumuskan masalah hipotesis, indikator identifikasi variabel, indikator interpretasi data, dan indikator 
merumuskan masalah mengalami peningkatan. Selain itu $N$-Gain pada kelas eksperimen lebih besar dibandingkan pada kelas kontrol, sehingga modul dengan model inkuiri efektif dalam menumbuhkan keterampilan proses sains siswa.

Penggunaan modul yang telah dikembangkan dapat menumbuhkan indikator keterampilan proses sains siswa pada indikator keterampilan memprediksi siswa dapat menafsirkan gambar atau fenomena sebagai hipotesis awal penelitian sebagaimana yang diungkapkan Sheeba (2013) pada penelitiannya.

Indikator merumuskan hipotesis dilihat dari siswa menjawab pertanyaan dari langkah-langkah yang telah dilakukan secara terinci. Hal ini sejalan dengan pernyataan Özgelen (2012) bahwa merumuskan hipotesis berkaitan dengan keterampilan berpikir mencipta (creativity).

Indikator keterampilan identifikasi variabel dapat dilihat dari siswa dapat menentukan variabel yang diuji berkaitan dengan fenomena yang diberikan sesuai dengan kriteria pada soal sebagaimana pernyataan (Komikesari, 2016) pemberian bantuan kepada siswa yang lebih terstruktur pada awal pembelajaran dan secara bertahap mengalihkan tanggung jawab belajar kepada siswa untuk bekerja atas arahan diri mereka sendiri.

Indikator keterampilan interpretasi dapat dilihat dari siswa sudah mulai melatih untuk memprediksi, membuat penyajian data yang disertakan dalam laporan pratikum. Hal ini sesuai dengan pernyataan (Özgelen, 2012) pada penelitiannya bahwa membuat prediksi, menarik kesimpulan, dan membuat hipotesis dari data yang dikumpulkan juga merupakan indikator keterampilan proses sains.

Indikator keterampilan merumuskan kesimpulan dapat dilihat dari siswa dapat menyimpulkan tujuan dari pembelajaran. Hal ini sesuai dengan pernyataan (Aydin,
2013) yang menyatakan bahwa menggambarkan kesimpulan adalah keterampilan proses pada level yang lebih tinggi.

Secara keseluruhan, pembelajaran inkuiri dapat menumbuhkan keterampilan proses sains. Hal ini sesuai dengan pendapat Weil \& Joyce (2000) yang menyatakan bahwa model pembelajaran inkuiri ini mengembangkan model inkuiri yang meliputi keterampilan proses yang meliputi pengamatan, mengumpulkan dan mengorganisasi data, mengidentifikasi dan mengontrol variabel, menguji dan merumuskan hipotesis, keterampilan menjelaskan dan inferensi.

Pembelajaran inkuiri yang diterapkan dapat menumbuhkan aspek keterampilan menyusun laporan siswa, hal ini sesuai dengan pernyataan yang dikemukakan oleh Bilgin (2009) yang mengatakan bahwa aktifitas pembelajaran dengan menggunakan inkuiri terbimbing membantu siswa untuk mengembangkan rasa tanggung jawab individu, metode kognitif, pembuatan laporan, penyelesaian masalah, dan kemampuan memahami.

Dengan demikian pembelajaran model inkuiri efektif untuk melatih keterampilan proses sains siswa. Hasil yang sama ditunjukkan oleh penelitian yang dilakukan oleh Rizal (2014) dan Nworgu \& Otum (2013) bahwa inkuiri dapat menumbuhkan keterampilan proses sains siswa.

\section{SIMPULAN DAN SARAN}

Modul dengan model inkuiri efektif digunakan dalam proses pembelajaran dilihat dari nilai $N$-Gain kelas eksperimen lebih besar dari kelas kontrol yang menggunakan modul konversional. Hasil penelitian menunjukkan bahwa modul dengan model inkuiri yang telah dikembangkan dapat menumbuhkan lima indikator keterampilan proses sains (KPS) siswa, yaitu memprediksi, merumuskan hipotesis, identifikasi variabel, 
interpretasi data, dan merumuskan kesimpulan.

Saran untuk penelitian selanjutnya dapat memodifikasi modul dengan pendekatan inkuiri untuk materi lain. Selanjutnya mencoba mengkombinasikan model pembelajaran dengan bantuan modul yang telah dikembangkan.

\section{DAFTAR PUSTAKA}

Aydin, A. (2013). Representation of Science Process Skills in The Chemistry Curricula For Grades 10, 11 and 12 / Turkey. International Journal of Education and Practice, 1(5), 51-63.

Bilgin, I. (2009). The Effects of Guided Inquiry Instruction Incorporating A Cooperative Learning Approach on University Students' Achievement of Acid and Bases Concepts and Attitude Toward Guided Inquiry Instruction. Scientific Research and Essay, 4(10), 1038-1046.

Dewi, P. S. (2016). Perspektif Guru sebagai Implementasi Pembelajaran Inkuiri Terbuka dan Inkuiri Terbimbing terhadap Sikap Ilmiah dalam Pembelajaran Sains. Tadris: Jurnal Keguruan Dan Ilmu Tarbiyah, 1(2), 179-186.

Erlinda, N. (2017). Peningkatan Aktivitas dan Hasil Belajar Siswa melalui Model Kooperatif Tipe Team Game Tournament pada Mata Pelajaran Fisika di SMK. Tadris: Jurnal Keguruan Dan Ilmu Tarbiyah, 2(1), 47-52.

Ertikanto, C. (2017). Perbandingan Kemampuan Inkuiri Mahasiswa Pendidikan Guru Sekolah Dasar dalam Perkuliahan Sains. Jurnal Ilmiah Pendidikan Fisika Al-Biruni, 6(1), 103.

Irwandani, I., \& Rofiah, S. (2015). Pengaruh Model Pembelajaran Generatif Terhadap Pemahaman Konsep Fisika Pokok Bahasan Bunyi Peserta Didik MTs Al-Hikmah
Bandar Lampung. Jurnal Ilmiah Pendidikan Fisika Al-Biruni, 4(2), 165-177.

https://doi.org/10.24042/jpifalbiruni. v4i2.90

Irwandani, Latifah, S., Asyhari, A., Muzannur, \& Widayanti. (2017). Modul digital interaktif berbasis articulate studio'13: pengembangan pada materi gerak melingkar kelas $\mathrm{x}$. Jurnal Ilmiah Pendidikan Fisika AlBiruni, 6(2), 221-231. https://doi.org/10.24042/jipfalbiruni. v6i2.1862

Iswatun, I., Mosik, M., \& Subali, B. (2017). Penerapan Model Pembelajaran Inkuiri Terbimbing untuk Meningkatkan KPS dan Hasil Belajar Siswa SMP Kelas VIII. Jurnal Inovasi Pendidikan IPA, 3(2), 150-160.

Komikesari, H. (2016). Peningkatan Keterampilan Proses Sains dan Hasil Belajar Fisika Siswa pada Model Pembelajaran Kooperatif Tipe Student Team Achievement Division. Tadris: Jurnal Keguruan Dan Ilmu Tarbiyah, 1(1), 15-22.

Meltzer, D. E. (2002). The Relationship between Mathematics Preparation and Conceptual Learning Gains in Physics: A Possible "Hidden Variable" in Diagnostic Pretest Scores. American Association of Physics Teachers, 1259-1268.

Nisrokhah. (2016). Pengembangan Modul Mata Kuliah Sejarah Pendidikan Islam di Sekolah Tinggi Ilmu Tarbiyah Pemalang. Jurnal Teknologi Pendidikan, 18(1), 43-52.

Nworgu, L. N., \& Otum, V. V. (2013). Effect of Guided Inquiry with Analogy Instructional Strategy on Students Acquisition of Science Process Skills. Journal of Education and Practice, 4(27), 35-41.

Özgelen, S. (2012). Students' Science Process Skills within a Cognitive Domain Framework. Eurasia 
Journal of Mathematics, Science and Technology Education, 8(4).

Parmin, \& Peniati, E. (2012). Pengembangan Modul Mata Kuliah Strategi Belajar Mengajar IPA berbasis Hasil Penelitian Pembelajaran. Jurnal Pendidikan IPA Indonesia, 1(1), 8-15.

Rizal. (2014). Pengaruh Pembelajaran Inkuiri Terbimbing dengan Multi Representasi terhadap Keterampilan Proses Sains dan Penguasaan Konsep IPA Siswa SMP. Jurnal Pendidikan Sains, 2(3), 159-165.

Sheeba, M. N. (2013). An Anatomy of Science Process Skills in The Light of The Challenges to Realize Science Instruction Leading to Global Excellence in Education. Educationa Confab, 2(4), 108-123.

Suparwoto. (2007). Pengembangan Bahan Ajar Bahan Kuliah Online. Bandung: Direktori UPI.

Weil, M., \& Joyce, B. R. (2000). Models of Teaching (6th ed.). Boston: Allyn and Bacon.

Wijayanti, W., Maharta, N., \& Suana, W. (2017). Pengembangan Perangkat Blended Learning Berbasis Learning Management System pada Materi Listrik Dinamis. Jurnal Ilmiah Pendidikan Fisika Al-Biruni, 6(1), 112.

Yamin, M. (2016). Peningkatan Hasil Belajar dan Aktivitas Matematika Siswa Melalui Strategi Pembelajaran Inkuiri pada Kelas XII IPA-2 SMAN 2 Bagan Sinembah Tahun Pelajaran 2014/2015. Jurnal EduTech, 2(1), 65-71. 